\title{
Code-switching in English Language Education: Voices from Vietnam
}

\author{
Nhan Trong Nguyen \\ Faculty of Science, Health, Education and Engineering, University of the Sunshine Coast, Australia \\ Peter Grainger \\ Faculty of Science, Health, Education and Engineering, University of the Sunshine Coast, Australia \\ Michael Carey \\ Faculty of Science, Health, Education and Engineering, University of the Sunshine Coast, Australia
}

\begin{abstract}
Why do bilingual language teachers and students switch between the two languages in their language classrooms? On the evidence of current research findings in relation to English-Vietnamese codeswitching in the educational contexts of Vietnam, this article identifies that classroom code-switching between the second language and the first language has its own pedagogic functions and it can be a valuable language classroom resource to both teachers and learners. In Vietnam, the implementation of the monolingual approach of teaching English-through-English-only faces many challenges such as inadequate classroom resources, students' low levels of English competence, motivation and autonomy, teachers' limited English abilities, and inappropriate teaching methods. Many Vietnamese teachers of English support code-switching in the classroom and they teach English through the bilingual approach. English-Vietnamese code-switching is reported not to be a restriction on the acquisition of English; rather, it can facilitate the teaching and learning of general English in Vietnam. This practice of code-switching is not just due to a lack of sufficient proficiency to maintain a conversation in English; rather, it serves a number of pedagogic functions such as explaining new words and grammatical rules, giving feedback, checking comprehension, making comparison between English and Vietnamese, establishing good rapport between teachers and students, creating a friendly classroom atmosphere and supporting group dynamics.
\end{abstract}

Index Terms — classroom code-switching, English, Vietnamese, pedagogic functions, bilingual, language education

\section{INTRODUCTION}

The debate on code-switching between English and the first language (L1) in English as a foreign/second language (EFL/ESL) classrooms has been ongoing for over 20 years (Macaro \& Lee, 2013). According to Harmer (2007), there has been a strong body of opinion supporting the English-only policy or monolingual approach in EFL/ESL education. Most advocates of the pure-English-input approach argue that the use of the L1 restricts EFL/ESL learners' exposure to the target language that is "an ideal source of language for student acquisition" (Harbord, 1992, p. 353). However, the literature on the functions of code-switching has seriously questioned this position. Many studies examining the use of more than one language in English language classrooms find that code-switching is a common phenomenon in bilingual and multilingual educational contexts, and both students and teachers code-switch for different reasons (Macaro, 2009; Sampson, 2012). Instead of impeding the English language teaching and learning, the purposeful and appropriate use of the mother tongue can facilitate the English teaching process and improve the learner's English competence (Miles, 2004; Vaezi \& Mirzaei, 2007). The bilingual approach which involves the use of both English and the learners' L1 recognizes that many learners need to operate in bilingual environments where translation and code-switching are valued skills (Sridhar \& Sridhar, 1986). The bilingual approach also acknowledges that many EFL/ESL learners wish to preserve their own cultural and linguistic identities while learning and using English (Seidlhofer, 2011).

In Vietnam, a national policy on the use of classroom languages in foreign language education has not been developed yet (Nguyen, 2013). Therefore, both English and Vietnamese can be used in English classes in Vietnam, and codeswitching between the two languages is popular in these classes (Canh, 2014). However, there are several Vietnamese EFL teachers, who strongly advocate the monolingual approach - Communicative Language Teaching (CLT) and have negative attitudes towards the use of the mother tongue in English language classrooms in Vietnam. The lack of a documented policy on the medium of instruction in foreign language education in Vietnam implies that there are also no formal guidelines or training materials for Vietnamese teachers on the use of classroom languages. The debate between Vietnamese supporters of the monolingual approach and those of the bilingual approach requires an official policy which explicitly designates the classroom language use in foreign language education in Vietnam. 
This article aims to guide Vietnamese policy makers on formulating an informed policy on the use of classroom languages in English language education in Vietnam, to contribute to the academic knowledge of code-switching in general English classrooms in Vietnam, and to raise awareness of the importance of the first language in the teaching and learning of EFL/ESL. In order to achieve those purposes, this paper summarises, analyses and discusses current research findings vis-à-vis (1) the pedagogic functions of classroom code-switching between the target language and the L1 in language education settings, (2) constraints on the implementation of the monolingual approach in Vietnam, and (3) English-Vietnamese code-switching in the context of general English education in Vietnam.

It is not a simple task to clearly define and distinguish code-switching, henceforth CS, from other terms of language contact phenomena. There have been different definitions of CS and other forms of bilingual behaviour (Kamwangamalu, 2010). In order to provide a focus and direction for this research, the following definitions are used. The term "code" is simply regarded as a verbal component which can be a morpheme, a word, a phrase, a clause or the entire system of language. In the EFL educational context of Vietnam, the definition of "code" certainly deals with only two different languages that are the first language, i.e. Vietnamese, and the target language, i.e. English. The term "code-switching" in this paper refers to "the juxtaposition within the same speech exchange of passages of speech belonging to two different grammatical systems or subsystems" (Gumperz, 1982, p. 59). Exploring CS from a sociolinguistic approach, this study looks for the functions of classroom CS occurring among teacher-student and student-student interactions in foreign/second language educational situations. For that reason, we view the term "codeswitching" from the functional perspective, which means that CS refers to any inter-sentential and intra-sentential alternating use of the target language and the mother tongue in an interactional discourse. The term "code-switching" is sometimes written as codeswitching or code switching. Our preference is to spell code-switching with a hyphen, and this preferred spelling of code-switching and its acronym (CS) will be used throughout this paper. However, original spelling of this term will be preserved in direct quotations and references.

\section{The Functions of Classroom Code-Switching Between the TARget LANGuage And the Mother Tongue}

CS in education or classroom CS involves the simultaneous use of the target language and the learners' L1, or two varieties (one standard and one nonstandard) of the target language, for classroom interactions and instructional exchanges (Kamwangamalu, 2010). Lin and Li (2012) state that there has been a well-established tradition of research on CS entailing the second language (L2) and the mother tongue in education, which is often complicated and controversial. The central debate in this research trend is about why bilingual teachers and students switch between the two languages in their classrooms and whether classroom code-switching is a resource or an obstacle to learning (Kamwangamalu, 2010). This section will provide an up-to-date review of the literature on the functions of codeswitching between the target language and the mother tongue in language education settings.

One of the most consistent findings in the TESOL literature is that both learners and teachers find the teachers' proficiency in the learners' first language as a positive and useful resource (Mahboob \& Lin, 2016). As summarised by Halliday (1994), the practice of switching to the mother tongue in second/foreign language classes has three main functions which are ideational functions, textual functions and interpersonal functions. Ideational functions include translating, explaining or annotating key L2 terms, and elaborating or exemplifying the L2 academic contents. Textual functions comprise highlighting or signaling topic shifts and marking out transitions between different activity types or different focuses. Interpersonal functions consist of sharing cultural values and negotiating shifts in frames, rolerelationships, identities and social distance.

Even in English teaching approaches where the L1 is supposed to be avoided, such as the Natural Approach (NA) and Communicative Language Teaching (CLT), there is still room for CS between English and the L1. While the NA states that an L2 can be taught best by using it naturally and actively through demonstration and actions without the learner's L1 (Richards \& Rodgers, 1986), Nunan and Lamb (1996) found that the NA teacher occasionally used the students' L1 in class. Investigating CS by teachers and learners in foreign language classrooms, Dailey-O'Cain and Liebscher (2009) show that many EFL students in CLT classes use their L1 as a resource. In addition, Newman (2014) argues that the use of CS in communicative classes can be seen as a facilitative tool to aid in and check the L2 comprehension and vocabulary acquisition; therefore, not allowing L2 learners, especially low proficiency learners, to use their L1 in communicative classes can be inhibiting to second language acquisition and learning.

In Content and Language Integrated Learning (CLIL), although an L2 is supposed to be used as a medium of instruction and learning for specialized subjects (Mehisto, Marsh, \& Frigols, 2008), CS to the L1 can work as an aid to the learning of both the subject contents and the L2 (Newman, 2014). Coyle, Hood, and Marsh (2010) state that in CLIL, "the systematic switch is based on a planned development of content, language and cognition" (p. 16). Besides, CS in CLIL classrooms can promote individual learning and can be seen as a part of scaffolding (Dailey-O'Cain \& Liebscher, 2009). The main functions of CS between the target language and the L1 in CLIL classrooms are to explain and summarise the lesson contents, to check comprehension and to build up the students' confidence (Coyle, Hood, \& Marsh, 2010).

García (2001) indicates that CS is not only a necessary pedagogical tool for teachers to effectively spread knowledge and information but it also accelerates second language acquisition and the academic use of that L2. In this sense, classroom CS can be seen as an aid to explain meanings of new words, to check learners' understanding and give 
feedback to individual learners (Zacharias, 2003), to promote solidarity with learners (Ferguson, 2003), to praise and scold students (Moodley, 2003), to give grammar instruction, manage the classroom, and to compensate for a lack of comprehension (Edstrom, 2006). Using the first language in a second language classroom can also raise the learners' awareness of the differences between the two languages, which can help them understand certain classes of errors (Deller, 2003; Schweers, 1999).

Exploring communication strategies used by learners of Japanese in foreign language learning environments, Grainger $(1997,2010,2012,2013)$ finds that the learners' CS is a spoken communication strategy related to interacting and compensating. These students intentionally switched to the native language in their Japanese classrooms to ask for meaning and to compensate for their low levels of Japanese proficiency (Grainger, 2013). Regarding learner autonomy and evaluation, Ellis (2003) argues that switching to the L1 allows EFL/ESL learners to give ongoing feedback about the course and their experiences of learning much more fluently than they do in English. Ellis also states that in the process of discovery and creation, the L1 use also facilitates the L2 learning.

In addition, classroom CS can be used to develop the speakers' identities and to negotiate changes in frames and rolerelationships. Canagarajah (2001) found that both teachers and students, by switching comfortably between Tamil and English, were simultaneously constructing their bilingual identities. Investigating CS in French-as-a-foreign-language classrooms in Thailand, Simon (2001) indicated that classroom CS was employed to negotiate different frames (formal institutional learning frame vs. informal friendly frame) and role-relationships (teacher vs. friend).

In short, empirical studies around the world show that CS between the target language and the mother tongue in foreign/second language classrooms is a communicative resource and it has three main functions which are ideational functions, textual functions and interpersonal functions. Language teachers and learners all over the world have used L2-L1 CS as an educational tool or a classroom aid to satisfy many different classroom needs such as developing rapport and solidarity among the class members, enhancing second language acquisition, managing the class, checking comprehension and giving feedback. The next section will problematize the implementation of the monolingual approach in Vietnam.

\section{CONSTRAints on the Implementation OF THE MONOLingual APPROACH IN Vietnam}

As pointed out earlier in this paper, Vietnam has not yet formulated an official policy on the medium of instruction in foreign language education (Nguyen, 2013). Therefore, both the monolingual approach and the bilingual approach have been used in English classes throughout Vietnam (Canh, 2014). While the effectiveness of the English-only policy in EFL/ESL education is still questioned in Vietnam, several Vietnamese teachers believe that an EFL classroom should be an English-only environment and they try to impose a ban on the use of Vietnamese in their EFL classes (Hoang, Jang, \& Yang, 2010).

Over the past decade, some English as a medium of instruction programs have been implemented at some Vietnamese universities, creating enormous difficulties for not only Vietnamese learners but also their teachers (Vu \& Burns, 2014). $\mathrm{Vu}$ and Burns indicate that when English is the exclusive means of communication in class, Vietnamese lecturers are challenged by their limited English abilities, teaching methods, students' English competence and learning styles, and inadequate classroom resources. These findings support those reported by Hickmann (2001) that academic difficulties result in an advocacy for second language instruction. This is also the reason why Sato and Kleinsasser (1999) argue that it is a mistake to underestimate the role of the L1 in the teaching and learning of an L2, and the dogmatic use of the target language may increase the learners' stress, frustration and embarrassment.

Hoang, Jang, and Yang (2010) conducted a study to re-examine the practice of English-only-instruction in terms of its pedagogical effectiveness and desirability in the tertiary EFL educational settings in Vietnam. Their findings indicated that the English-only policy failed to guarantee the majority (70\%) of the students' sufficient understanding of the lessons. Moreover, roughly two thirds of the sampled students admitted having difficulties expressing their thoughts and communicating with others in the target language. Regarding the learners' attitudes, approximately $55 \%$ of the students confirmed their deep prejudice against the English-only policy, and around $70 \%$ of them endorsed the use of Vietnamese as a contributory teaching and learning medium.

It is generally assumed that the world of English language teaching (ELT) has witnessed an era of methodology improvements and innovation since the monolingual approach - Communicative Language Teaching (CLT) came into existence in Western English-speaking countries in the 1970s (Richards, 2002). CLT proposes that learning a language is not only knowing a set of grammatical, lexical and phonological rules but also developing an ability to use that language effectively for real communicative needs; therefore, the first language should be avoided in communicative English classes (Larsen-Freeman, 1986). According to Barnard and Viet (2010, p. 78), CLT has been espoused as a pedagogical innovation and "the guiding principle of many national curricula in Asian school systems, as elsewhere." However, Bax (2003) and Littlewood (2007) report that the transfer of CLT from the Western contexts to Asian countries like Japan, Korea and China is problematic. Empirical studies in Vietnam (Hiep, 2004, 2007) also found a mismatch between CLT tenets and the local classroom cultures. For example, CLT principles such as "changing teachers' and students' roles, and breaking down hierarchic barriers in the classroom" (Larsen-Freeman, 2000, p. 66) challenge the basic socio-cultural values of the formal Vietnamese classroom, where the power distance or the 
hierarchic relationship between teacher-as-superior and student-as-inferior is very distinctive (Nhan \& Lai, 2012b, 2012c).

Hiep (2007, p. 195) argues that in English speaking countries, immigrants learn English to communicate with native speakers of English, so it is necessary that English classes operate "on the principle of immersing learners in AngloSaxon society." However, when this principle is applied in Vietnam, many issues emerge because the socio-cultural, political, and physical conditions of Vietnam markedly differ from those in the UK or the USA. As described by Brown (1994), practices in CLT classrooms include the use of authentic language input in real life contexts to encourage learners to produce the target language for genuine and meaningful communication. Nevertheless, Hiep (2007) states that as Vietnamese students of English share the same mother tongue - Vietnamese, they do not have the immediate need to use the target language - English in the classroom, and nor most of them have this need outside the classroom. Therefore, Hiep (2007) questions the applicability of the in-class CLT tasks to the world outside the classroom, and he wonders if Vietnamese learners are really engaged in genuine communication when they are asked to do tasks in English only. Moreover, many Vietnamese learners find it difficult to read English authentic texts (as opposed to simplified texts created by language book publishers) and they only practise reading in English under compulsion by teachers (Nhan \& Lai, 2013).

Before learning an L2, each learner has a ready-made knowledge system of his/her L1, so a ban on the L1 sounds unreasonable because people naturally tend to communicate in the best way they can, i.e. in their first most fluent language. That is also the reason why Le (2005) argues that L2 learners feel more secure when they are allowed to switch to their mother tongue. In line with Le's (2005) argument, Nhan and Lai (2012a) state that equivalents in the first language should be given where possible to EFL learners, especially beginners, in order to help them understand more. This will also help them combine different words in English in different ways to produce new sentences.

In short, research shows that the monolingual approach - CLT may be not applicable in some contexts. The concept of avoiding the mother tongue in EFL/ESL education should be reconsidered, and the application of CLT as well as its influence upon the teaching and learning of EFL/ESL should be critically discussed in different education settings. In the Vietnamese educational situations, the implementation of the monolingual approach has been constrained by inadequate classroom resources, teachers' limited English abilities, teaching methods, students' low levels of English competence, motivation and autonomy. The following section will describe the CS practice in general English classrooms in Vietnam.

\section{Code-Switching in General English Classrooms in Vietnam}

Although there are not many studies on classroom code-switching between English and Vietnamese, they all arrive at the conclusion that English-Vietnamese CS commonly occurs in general English classes in Vietnam (Canh, 2014). Research shows that classroom CS is not detrimental to the general English teaching and learning, but a useful and important resource for both Vietnamese students and instructors (Nguyen, 2013). In addition, CS between English and Vietnamese has been widely supported by both Vietnamese students and teachers (Hien, 2012; Hoang, Jang, \& Yang, 2010). It is not true that Vietnamese EFL teachers and learners switch to Vietnamese just because of their lack of linguistic competence in English; this section will point out the pedagogic functions of code-switching in general English classrooms in Vietnam.

According to Huong (2006) switching to the mother tongue helps Vietnamese students feel more at ease in learning English and thus supports their second language acquisition. In addition, Oanh (2006) notes that when Vietnamese EFL students use their first language among themselves and with the teacher, it has a positive effect on group dynamics. Apart from formal teaching and learning, jokes and small-talk in the learners' first language can establish good rapport among students and between teachers and students, which helps create a friendly classroom atmosphere (Nhan \& Lai, 2012a).

Studying attitudes of Vietnamese university teachers and students about the use of both English and the mother tongue in EFL classrooms in Vietnam, Anh (2009) reported that most of the participants held a supportive view on English-Vietnamese CS. Focusing on the functions of Vietnamese EFL teachers' CS, Hien (2012) found that switching to Vietnamese mainly served the ideational functions, as categorised by Halliday (1994), which are to explain vocabulary, clarify grammatical rules, make comparisons between English and Vietnamese, check the learners' comprehension and give feedback to individuals. Moreover, Hien found that some teachers carefully prepared their CS practice in their lesson plans. Vietnamese teachers of EFL tend to speak English to their students first, and then switch to Vietnamese as a translation to ensure the low-level students' sufficient understanding of meta-language (Canh, 2014).

In order to explore factors affecting CS in tertiary English classrooms in Vietnam, Tien (2012) conducted a case study on one teacher teaching two different general English classes at two universities in Ho Chi Minh City, Vietnam. He indicated that CS in the research context was influenced by contextual factors such as the class timetabling, the learners' English proficiency levels and cultural values, teacher evaluation systems and teacher cognition. His investigation also revealed that more CS occurred in the public university than in the private one due to the lower English proficiency learners at the public university, and inter-sentential CS was dominant compared to intra-sentential $\mathrm{CS}$, which suggests that the choice to CS was deliberate rather than the result of a lack of vocabulary or control of 
syntax. Tien (2012) concluded that the EFL teacher used CS as a communicative and facilitative tool to check and reinforce her Vietnamese learners' English comprehension and vocabulary acquisition.

Nhan and Lai (2012a) state that each EFL/ESL student's background knowledge and identity are formed through his/her mother tongue, and his/her natural inclination to communicate in the first language is non-negotiable. Whether teachers like it or not, their Vietnamese learners of EFL, especially low proficiency learners, are still thinking in both Vietnamese and English, and CS between English and Vietnamese just naturally happens in the classroom. In addition, Nhan and Lai (2012a) point out considerable benefits of classroom CS to both language teachers and students, and argue that Vietnamese EFL teachers can use CS as a classroom aid to enhance their teaching practice and get more success with lower-level students.

In short, despite the dominance of CLT in many countries around the world, research on classroom CS in Vietnam reveals that CLT is not always the case. English-Vietnamese CS has gained good support from many Vietnamese EFL teachers and students, and it has been reported not to be an obstacle but an effective strategy in the teaching and learning of general English in Vietnam. English-Vietnamese CS in general English classes has performed a number of pedagogical functions such as enhancing second language acquisition, explaining new words and grammar, making comparisons between the two languages, checking students' understanding and giving feedback to individuals. Besides, Vietnamese EFL learners and instructors have used their familiar local language in the unfamiliar target language classroom to establish close rapport between them, create a friendly classroom atmosphere and support group dynamics.

\section{CONCLUSION}

English language education has been in the Post Methods era which lays an emphasis on the process of teaching, the understanding of language and how learning takes place rather than ascribing the success of ELT to pedagogic methods (Richards \& Lockhart, 1996). Studies in Vietnam and other Asian countries such as Japan (Nishino \& Watanabe, 2008), Thailand (Tayjasanant \& Barnard, 2010), China (Hu, 2002) and Korea (Yoon, 2004) found a mismatch between CLT tenets and local classroom cultures. Therefore, it is recommended that every EFL/ESL teacher be flexible and innovative in adopting and adapting new pedagogical approaches in their own educational contexts.

Although the monolingual imperatives dominate language teaching theories and second language acquisition research (Cook, 2008), L2-L1 CS commonly occurs in many language classrooms all around the world, especially in classrooms where teachers and students share the same mother tongue. Research shows that foreign/second language teachers and learners have their own pedagogic motivations for L2-L1 CS, and this practice of code-switching has many positive impacts on the teaching and learning of a foreign/second language. L2-L1 CS has been used as an educational tool to satisfy many different classroom needs and it serves three main functions which are ideational, textual and interpersonal functions.

In the educational situations of Vietnam, the concept of avoiding the first language in the teaching and learning of EFL does not work well due to inadequate classroom resources, teachers' limited English abilities, teaching methods, students' low levels of English competence, motivation and autonomy. CS between English and Vietnamese exists in many general English classrooms and it has been supported by many Vietnamese learners and teachers of EFL. The primary functions of CS in general English education settings in Vietnam are to explain vocabulary, clarify grammar, give feedback, compensate for a deficiency of comprehension, compare and contrast English with Vietnamese, build good rapport between learners and teachers, create a friendly classroom atmosphere and facilitate group dynamics. In addition, CS in the EFL educational environment in Vietnam is affected by contextual factors such as students' English proficiency and cultural values, the testing and evaluation systems, the class timetabling and teacher cognition.

Classroom CS has been proved to be an important resource for second/foreign language teachers. Lower proficiency learners, up until the intermediate level, rely more on and benefit from CS in the classroom, but it is possibly not as beneficial in the learning progress for students who wish to advance beyond that stage of proficiency. Vietnamese teachers, educators and policy makers should keep reasonably informed of not only the influences of CS on the teaching and learning of EFL but also other new emerging challenges and achievements in other educational contexts in Vietnam. The absence of an official policy on the medium of instruction in foreign language education in Vietnam should not continue, and there should be formal guidelines and training materials for Vietnamese schools and teachers on how to maximise the benefits of CS in the classroom.

Most of the studies on classroom CS between English and Vietnamese that have been discussed in this paper used survey and/or interview data. This means that only some of them were based on an analysis of the actual classroom language use. Therefore, Vietnam needs more instruction-based and classroom-practice-based studies which provide more descriptions of the actual practice of CS inside the classroom.

In addition, the literature on English-Vietnamese CS reveals that studies conducted in Vietnam only focus on EFL teachers' attitudes towards CS in their general English classes, and there has been no published research on CS by both teachers and learners in the contexts of English for specific purposes or English for academic purposes. This gap in the literature needs to be addressed in order to create a better understanding of both students' and teachers' practice-based perspectives on classroom code-switching in different contexts in Vietnam. 


\section{REFERENCES}

[1] Anh, K. H. K. (2009). Use of Vietnamese in English language teaching in Vietnam: Attitudes of Vietnamese university teachers and students. M.A. thesis, HoChiMinh City Open University, Vietnam.

[2] Barnard, R. \& N. G. Viet (2010). Task-based language teaching (TBLT): A Vietnamese case study using narrative frames to elicit teachers' beliefs. Language Education in Asia 1.1, 77-86.

[3] Bax, S. (2003). The end of CLT: A context approach to language teaching. ELT Journal 57.3, 278-287.

[4] Brown, H. D. (1994). Principles of language learning and teaching. Englewood Cliffs, NJ: Prentice Hall Regents.

[5] Canagarajah, S. (2001). Constructing hybrid postcolonial subjects: Codeswitching in Jaffna classrooms. In M. Heller \& M. Martin-Jones (eds.), Voices of authority: Education and linguistic difference. Westport, CT \& London: Ablex, 193-212.

[6] Canh, L. V. (2014). Codeswitching in universities in Vietnam and Indonesia. In R. Barnard \& J. McLellan (eds.), Codeswitching in university English-medium classes: Asian perspectives. Bristol, UK: Multingual Matters, 118-131.

[7] Cook, V. (2008). Second language learning and language teaching. London: Hodder Education.

[8] Coyle, D., P. Hood \& D. Marsh (2010). CLIL: Content and language integrated learning. Cambridge: Cambridge University Press.

[9] Dailey-O'Cain, J. \& G. Liebscher (2009). Teacher and student use of the first language in foreign language classroom interaction: Functions and applications. In M. Turnbull \& J. Dailey-O'Cain (eds.), First language use in second and foreign language learning. Bristol, UK: Multingual Matters, 131-145.

[10] Deller, S. (2003). The language of the learner. English Teaching Professional 26, 5-7.

[11] Edstrom, A. (2006). L1 use in the L2 classroom: One teacher's self-evaluation. The Canadian Modern Language Review 63.2, 275-292.

[12] Ellis, E. M. (2003). Bilingualism among teachers of English as a second language: A study of second language learning experience as a contributor to the professional knowledge and beliefs of teachers of ESL to adults. Ph.D. dissertation, Griffith University, Brisbane, Australia.

[13] Ferguson, G. (2003). Classroom code-switching in post-colonial contexts: Functions, attitudes and policies. AILA Review 16, $38-51$.

[14] García, O. (2001). Bilingual education is beneficial. In M. E. Williams (ed.), Education; opposing viewpoints. San Diego: Greenhaven Press, 126-129.

[15] Grainger, P. (2012). The impact of cultural background on the choice of language learning strategies in the JFL context. System 40, 483-493.

[16] Grainger, P. R. (1997). Language-learning strategies for learners of Japanese: Investigating ethnicity. Foreign Language Annals 30.3, 378-385.

[17] Grainger, P. R. (2010). Spoken communication strategies used by learners of Japanese in a foreign language learning environment. Ph.D. dissertation, University of Queensland, Brisbane, Australia.

[18] Grainger, P. R. (2013). Bedrock/Core, Base, Plus, and Threshold strategies in the JFL context. Foreign Language Annals 45.4, 599-621.

[19] Gumperz, J. (1982). Discourse strategies. Cambridge: Cambridge University Press.

[20] Halliday, M. A. K. (1994). An introduction to functional grammar. London: Edward Arnold.

[21] Harbord, J. (1992). The use of the mother tongue in the classroom. ELT Journal 46.4, 350-355.

[22] Harmer, J. (2007). The practice of English language teaching. Harlow, England: Pearson Education.

[23] Hickmann, M. (2001). Language and cognition in development: Old questions, new directions. Pragmatics 11.2, 105-126.

[24] Hien, P. T. (2012). An investigation into teachers' use of Vietnamese in English classrooms for young learners at a language centre. M.A. thesis, Hanoi National University, Vietnam.

[25] Hiep, P. H. (2004). Trained in the West, teaching in the East: Vietnamese teachers returning from TESOL courses abroad. Ph.D. dissertation, University of Melbourne, Victoria, Australia.

[26] Hiep, P. H. (2007). Communicative language teaching: Unity within diversity. ELT Journal 61.3, 193-201.

[27] Hoang, N. T. B., S. H. Jang \& Y. Yang (2010). English-Only classrooms: Ideology versus reality. Paper presented at the 2010 AARE Annual Conference, Melbourne. http://www.aare.edu.au/data/publications/2010/1755HoangJangYang.pdf (access 28/11/2014).

[28] Hu, G. (2002). Potential cultural resistance to pedagogical imports: The case of communicative language teaching in China. Language, Culture and Curriculum 15.2, 93-105.

[29] Huong, T. N. N. (2006). Linguistic imperialism, English as an international language, and Vietnam. Teacher's Edition 20, 2733.

[30] Kamwangamalu, N. M. (2010). Multilingualism and codeswitching in education. In N. H. Hornberger \& S. L. McKay (eds.), Sociolinguistics and language education. UK: Multilingual Matters, 116-142.

[31] Larsen-Freeman, D. (1986). Techniques and principles in language teaching. Oxford: Oxford University Press.

[32] Larsen-Freeman, D. (2000). On the appropriateness of language teaching methods in language and development. In J. Shaw, D. Lubelska \& M. Noullet (eds.), Partnership and Interaction: Proceedings of the fourth international conference on language and development. Bangkok: Asian Institute of Technology, 65-72.

[33] Le, N. T. C. (2005). From passive participant to active thinker: A learner-centered approach to materials development. English Teaching Forum 43.3, 2-9.

[34] Lin, A. Y. M. \& D. C. S. Li (2012). Code-switching. In M. Martin-Jones, A. Blackledge \& A. Creese (eds.), The Routledge handbook of multilingualism. Oxford: Routledge, 470-481.

[35] Littlewood, W. (2007). Communicative and task-based language teaching in East Asian classrooms. Language Teaching 40, 243-249. 
[36] Macaro, E. (2009). Teacher use of code switching in the second language classroom: Exploring "optimal” use. In M. Turnbull \& J. Dailey-O'Cain (eds.), First language use in second and foreign language learning. Cambridge: Cambridge University Press, 35-49.

[37] Macaro, E. \& J. H. Lee (2013). Teacher language background, codeswitching, and English-only instruction: Does age make a difference to learners' attitudes? TESOL Quarterly 47.4, 717-742.

[38] Mahboob, A. \& A. M. Y. Lin (2016). Using local languages in English language classrooms. In W. A. Renandya \& H. P. Widodo (eds.), English language teaching today: Building a closer link between theory and practice. New York: Springer, 118.

[39] Mehisto, P., D. Marsh \& M. J. Frigols (2008). Uncovering CLIL. UK: Macmillan.

[40] Miles, R. (2004). Evaluating the use of L1 in the English language classroom. M.A. thesis, University of Birmingham, UK.

[41] Moodley, V. (2003). Language attitudes and codeswitching behaviour of facilitators and learners in language, literacy and communication senior phase outcomes-based education classrooms. Ph.D. dissertation, University of Natal, KwaZulu-Natal, South Africa.

[42] Newman, I. H. (2014). Code-switching: Using L1 and L2 in bilingual education - The case of Asturias. M.A. thesis, University of Oviedo, Asturias, Spain.

[43] Nguyen, T. H. (2013). Vietnamese university EFL teachers' code-switching in classroom instruction. Ph.D. dissertation, Auckland University of Technology, Auckland, New Zealand.

[44] Nhan, N. T. \& H. T. Lai (2012a). The current state of the art in ELT with special reference to the use of the first language in EFL classes in Vietnam. Language in India 12.3, 558-575.

[45] Nhan, N. T. \& H. T. Lai (2012b). The enhancement of learner autonomy and the growth of English language proficiency. Language in India 12.4, 427-439.

[46] Nhan, N. T. \& H. T. Lai (2012c). The influences of age and power relations on Vietnamese tertiary students of non-English majors in making spoken invitations in English. Theory and Practice in Language Studies 2.5, 902-908.

[47] Nhan, N. T. \& H. T. Lai (2013). A comparison on the use of language learning strategies by male and female Vietnamese tertiary students of non-English majors. Language in India 13.4, 185-210.

[48] Nishino, T. \& M. Watanabe (2008). Communication-oriented policies versus classroom realities in Japan. TESOL Quarterly $42.1,133-138$

[49] Nunan, D. \& C. Lamb (1996). The self-direct teacher: Managing the learning process. Cambridge: Cambridge University Press.

[50] Oanh, D. T. H. (2006). Community values and classroom dynamics in Vietnam. Teacher's Edition 20, 35-42.

[51] Richards, J. C. (2002). 30 years of TEFL/TESL: A personal reflection. RELC Journal 33.2, 1-35.

[52] Richards, J. C. \& C. Lockhart (1996). Reflective teaching in second language classrooms. Cambridge: Cambridge University Press.

[53] Richards, J. C. \& T. S. Rodgers (1986). Approaches and methods in language teaching. Cambridge: Cambridge University Press.

[54] Sampson, A. (2012). Learner code-switching versus English only. ELT Journal 66.3, 293-303.

[55] Sato, K. \& R. Kleinsasser (1999). Communicative language teaching (CLT): Practical understandings. Modern Language Journal 83.4, 494-517.

[56] Schweers, C. W. Jr. (1999). Using L1 in the L2 classroom. English Teaching Forum 37.2, 6-9.

[57] Seidlhofer, B. (2011). Understanding English as a Lingual Franca. Oxford: Oxford University Press.

[58] Simon, D. L. (2001). Towards a new understanding of codeswitching in the foreign language classroom. In R. Jacobson (ed.), Codeswitching worldwide 2. Berlin and New York: Mouton de Gruyter, 311-342.

[59] Sridhar, K. \& S. Sridhar (1986). Bridging the paradigm gap: Second language acquisition theory and indigenized varieties of English. World Englishes 5.1, 3-14.

[60] Tayjasanant, C. \& R. Barnard (2010). Language teachers' beliefs and practices regarding the appropriateness of communicative methodology: A case study from Thailand. Journal of Asia TEFL 7.2, 277-311.

[61] Tien, N. Q. (2012). English-Vietnamese code-switching in tertiary educational context in Vietnam. Asian Englishes 15.2, 4-29.

[62] Vaezi, S. \& M. Mirzaei (2007). The effect of using translation from L1 to L2 as a teaching technique on the improvement of EFL learners' linguistic accuracy - focus on form. Humanising Language Teaching 9.5. http://www.hltmag.co.uk/Sep07/mart03.htm (accessed 1/12/2014).

[63] Vu, N. T. T. \& A. Burns (2014). English as a medium of instruction: Challenges for Vietnamese tertiary lecturers. The Journal of ASIA TEFL 11.3, 1-31.

[64] Yoon, K. (2004). CLT theories and practices in EFL curricula: A case study of Korea. Asian EFL Journal 6.3, 1-16.

[65] Zacharias, N. T. (2003). A survey of tertiary teachers' beliefs about English language teaching in Indonesia with regard to the role of English as a global language. M.A. thesis, Assumption University, Bangkok, Thailand.

Nhan Trong Nguyen is a Lecturer at English Department, Ho Chi Minh City University of Transport, Vietnam. He obtained his MA in Applied Linguistics from Curtin University of Technology, Australia, and Postgraduate Diploma in TESOL from SEAMEO RELC, Singapore. Currently, he is a PhD candidate at the University of the Sunshine Coast, Australia, where he is investigating classroom code-switching between English and Vietnamese. His primary research interests are sociolinguistics, pragmatics and second language acquisition.

Peter Grainger is an Applied Linguist with a $\mathrm{PhD}$ in the field of second language acquisition from the University of Queensland, Australia. He has taught in four universities in Queensland (Griffith University, CQUniversity, James Cook University and the 
University of the Sunshine Coast). His research focuses are assessment (grading tools), second language learning (Japanese) and more recently, Peer Review processes in tertiary educational institutions.

Michael Carey is an expert in TESOL with a PhD in Applied Linguistics. He has taught and conducted research within linguistics since 1992 in the fields of TESOL, speech science (perception and pronunciation modification), academic writing, language testing and assessment, and preparation for IELTS. Dr Michael Carey's teaching role at the University of the Sunshine Coast includes coordination for the combined secondary Education programs and teaching language and literacy courses. 